\title{
Nigeria and the Selenium Micronutrient: A Review
}

\author{
MJ Adeniyi* and FO Agoreyo \\ Department of Physiology, University of Benin, Nigeria
}

Submission: January 19, 2018; Published: April 13, 2018

*Corresponding author: MJ Adeniyi, Department of Physiology, University of Benin, Benin-city, Nigeria, Tel: +234 08066796517; Email: 7jimade@gmail.com

\begin{abstract}
Local studies have documented the contributions of minerals to the health status of mammals. Selenium (Se) is an example of such minerals. It is essential for the activation and functioning of enzymes. In Nigeria, the mineral has been reported to be present in water, foods and soils. While the soil selenium concentrations determine selenium levels in foods, difference in food concentrations of the mineral atones for the variations in the plasma and tissue selenium level across the geopolitical zones of Nigeria. Areas in Nigeria prone to erosion could be associated with inadequate soil selenium levels and this might lead to low availability of the mineral in the foods consumed by animals and humans. The plasma selenium levels in Nigerians may vary from as low as $0.006 \mathrm{mg} / \mathrm{L}$ to as high as $0.3279 \pm 0.0546 \mathrm{mg} / \mathrm{L}$ depending on the geographical factors and analytical methods employed. Studies in which the physiological effects of selenium supplementations were investigated revealed an improvement in CD4 counts in HIV positive human subjects, reduction in rats' susceptibility to trypanosomiasis, improvement in reproductive function, acceleration of ulcer healing in animal model of experimental gastric ulcer and mitigation of the adverse effects in animal model of gastric ulcer. Low plasma selenium levels are associated with HIV infection, fertility problems, postpartum cardiomyopathy and diabetes mellitus. Therefore, there is growing need for dietary selenium supplementations in Nigeria.
\end{abstract}

Keywords: Selenium; Supplementations; Nigeria; Geopolitical; Nigerian; Mineral

\section{Introduction}

Nutrition deals with food substances and their effects on health [1]. Food substances including non-energy yielding substances like selenium are required for metabolisms [2] (Figure 1). Selenium is an element of the Periodic Table and it is present in soil, water, rock and food. As far as Nigeria is

concerned, studies revealed that the soil concentrations of the mineral vary across the six geopolitical zones of the country. This results in variation in concentration of the mineral in plant and animal foods consumed by Nigerians Rayman [3] and Combs [4] and difference in selenium level in body fluid and tissues $[5,6]$.

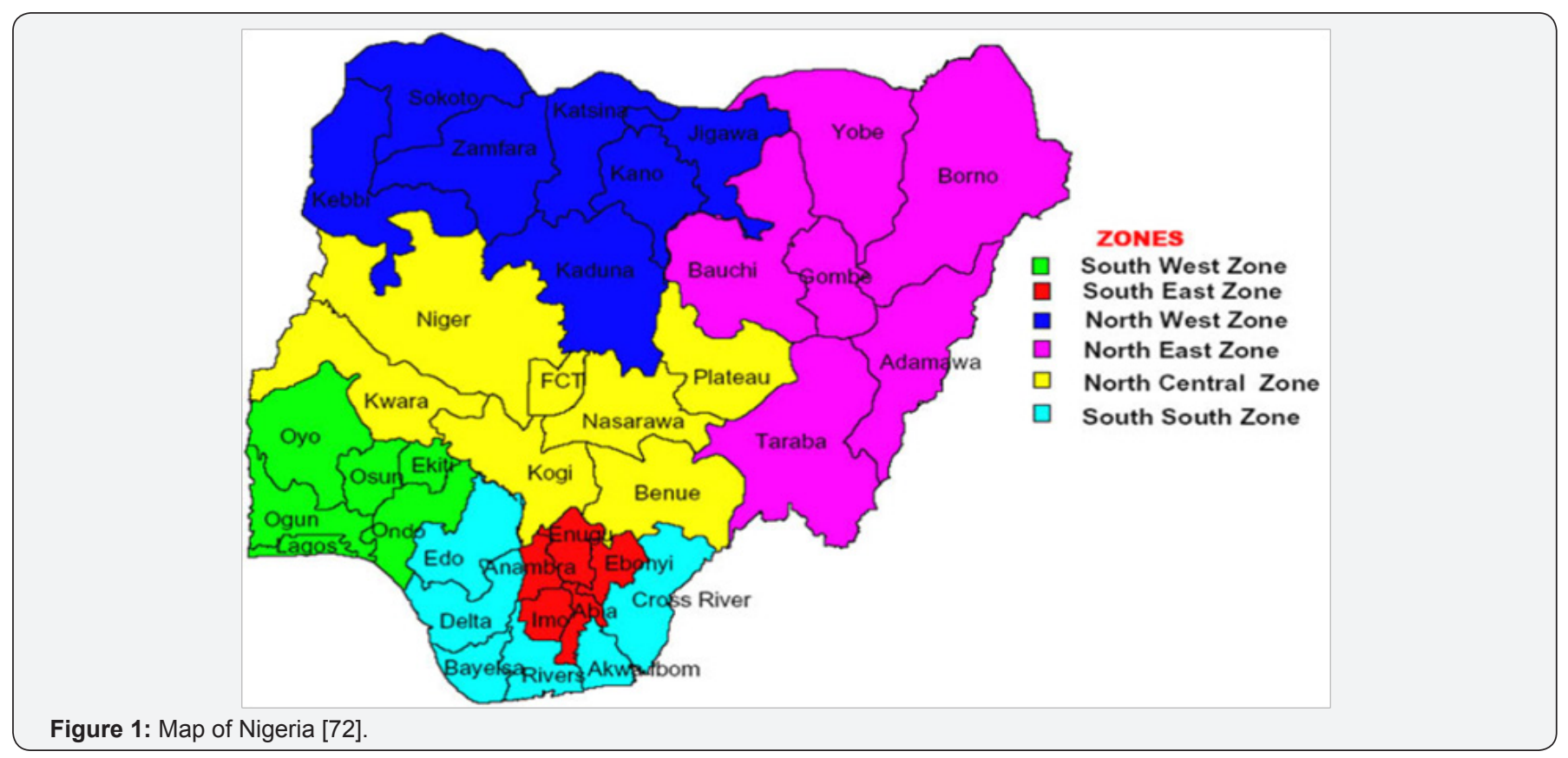

Curr Trends Biomedical Eng \& Biosci 14(1): CTBEB.MS.ID.555876 (2018) 
As a vital component of antioxidant enzymes [7] (Figure 2) and iodothyronine deiodinase [8], the mineral mediates many functions in humans and animals. For instance, selenium improved glutathione peroxidase and CD4 count in HIV positive Nigerian patients [9-11]. It also exerted a positive influence on male reproductive function [12] and accelerated gastric ulcer healing in an animal study [13]. The mineral is essential for cardiovascular health [14] and endocrine functions [15]. Selenium has also been shown to possess insulinotropic [16], antioxidant [7] and anticancer effects [12]. Selenium, among other functions, reduced susceptibility to infection in rats [18].

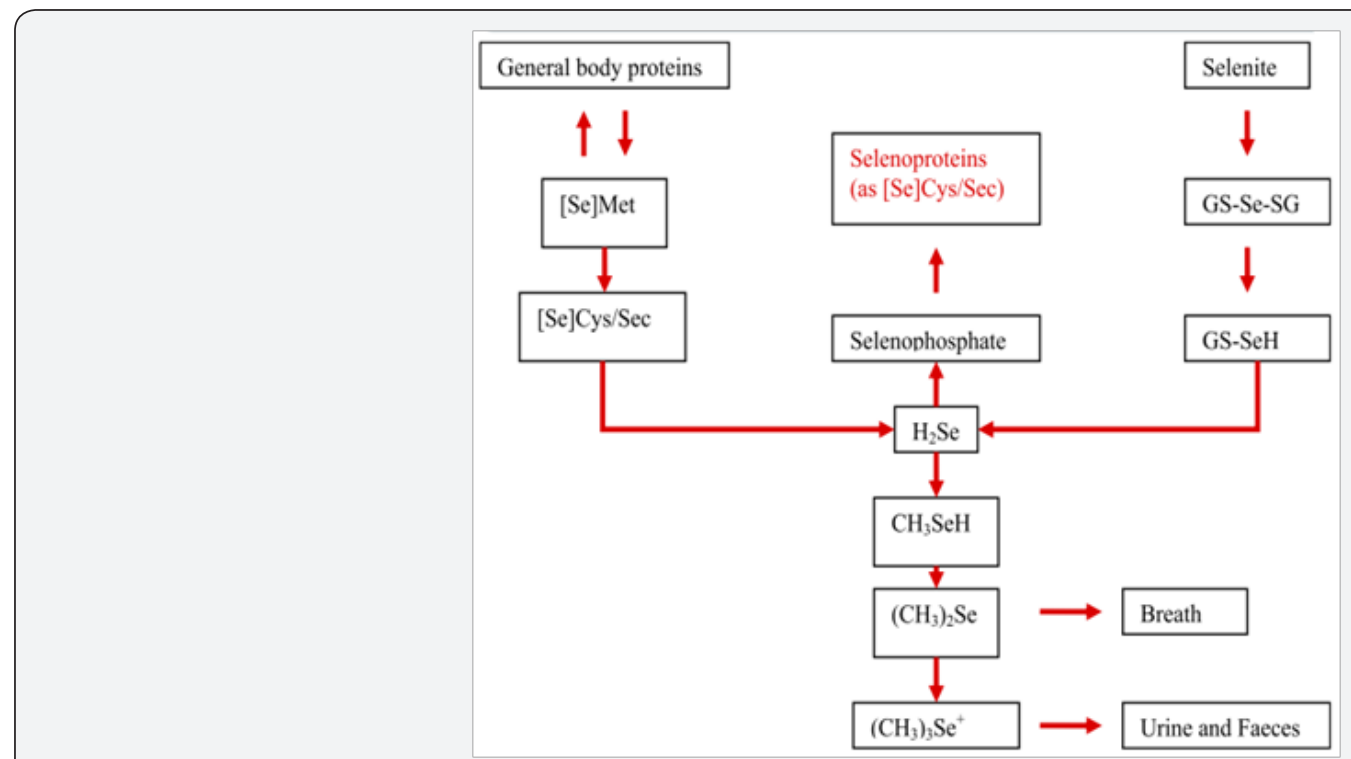

Figure 2: Metabolic pathway of selenium [8].

The purpose of this work is to highlight trends in selenium research and the physiological significance of its supplementations in Nigeria.

\section{Selenium}

\section{Chemistry of selenium}

Selenium is a metalloid located in period IV and group VI of the Periodic Table. It has atomic number 34 and mass number of 79 with oxidation states of $+6,+5,+4,+3,+2,+1$ and -1 [19].

Table 1: Mammalian selenoproteins [22].
It rarely occurs in its elemental state in nature, or as pure ore compounds [19]. Selenium forms two oxides: selenium dioxide and selenium trioxide. Selenium dioxide dissolves in water to form selenous acid. Salts of selenous acid are called selenites and these include silver selenite and sodium selenite, the inorganic forms of selenium. Selenium forms hydrogen selenide $\left(\mathrm{H}_{2} \mathrm{Se}\right)$ which is toxic and colourless. Selenium forms stable bonds to carbon giving rise into selenols. Examples of selenols are diphenyldiselenide, benzeneselenol and selenomethionine, the organic forms of selenium [19] (Table 1).

\begin{tabular}{|c|c|c|}
\hline S/n & Selenoprotein & Proposed Function \\
\hline 1 & GPx & Antioxidant In cell cytosol; Se store \\
\hline 2 & GPx1 & Antioxidant In gastrointestinal tract \\
\hline 3 & GPx2 & Antioxidant In extracellular space and plasma \\
\hline 4 & GPx3 & $\begin{array}{c}\text { Antioxidant In membranes, structural protein } \\
\text { in sperm: apoptosis }\end{array}$ \\
\hline 5 & GPx4 & Unknown \\
\hline 6 & GPx5 & $\begin{array}{c}\text { GPx1 homolog? } \\
\text { oxidoreductase Detoxifies peroxides, reduces } \\
\text { thioredoxin (control of cell growth): maintains } \\
\text { redox state of transcription factors }\end{array}$ \\
\hline 7 & GPx6 & Mainly cystosolic, ubiquitous \\
\hline 8 & Thiredoxin reductase (TR) & Expressed by testes \\
\hline
\end{tabular}


Current Trends in Biomedical Engineering \& Biosciences

\begin{tabular}{|c|c|c|}
\hline 10 & TR3 & Mitochondrial, ubiquitous \\
\hline 11 & Iodothyronine deiodinases & \\
\hline 12 & Types D1 AND D2 & $\begin{array}{l}\text { Converts thyroxine (T4) to bioactive } 3,6,3^{\prime} \text {-tri- } \\
\text { iodothyronine (T3) }\end{array}$ \\
\hline 13 & Types D1 and D3 & Converts T4 to to inactive $3^{\prime}, 3^{\prime}, 5^{\prime}$ reverse $\mathrm{T} 3$ \\
\hline 14 & Salenoprotein P & $\begin{array}{c}\text { Selenium transport protein, antioxidant in } \\
\text { endothelium }\end{array}$ \\
\hline 15 & Salenoprotein W & Antioxidants in cardiac and skeletal muscle \\
\hline 16 & Salenophosphate synthetase (SPS2) & $\begin{array}{l}\text { Synthesis of selenophosphate for } \\
\text { selenoprotein synthesis }\end{array}$ \\
\hline 17 & 15kDa selenoprotein (sep 15) & Protects against cancer \\
\hline 18 & Selenoproteins $\mathrm{H}, \mathrm{I}, \mathrm{K}, \mathrm{M}, \mathrm{N}, \mathrm{O}, \mathrm{P}, \mathrm{R}, \mathrm{S}, \mathrm{T}, \mathrm{V}$ & Role largely unknown \\
\hline
\end{tabular}

The mineral was first discovered in 1817 by Jons Jacob Berzelius when investigating the chemicals responsible for outbreaks of ill health among workers in a Swedish sulphuric acid plant [20]. Klaus Schwarz proved selenium is an essential nutrient necessary for both normal growth and reproduction in animals [21] (Table 2).

Table 2:Selenium concentrations in Nigerian foods [6].

\begin{tabular}{|c|c|}
\hline Sample & Mean \pm SD \\
\hline Cereals & \\
\hline Millet (Sorghum vulgare) & $5 \pm 3.4$ \\
\hline Rice (white) (Zea mays) & $5 \pm 2.5$ \\
\hline Meat and Fish & $15 \pm 4.5$ \\
\hline Fish (dry) ( Tilapia nicotilus) & $20 \pm 5.2$ \\
\hline Cray fish (Procambaris clarkia) & $<2 \pm 3.2$ \\
\hline Snail (Achatina fulica) & $<1 \pm 8.4$ \\
\hline Wistar strain (albino rat) & \\
\hline Milk and dairy product & $5 \pm 3.5$ \\
\hline Milk (powder) & $<1 \pm 8.4$ \\
\hline Egg (yolk) & $<2 \pm 3.2$ \\
\hline Egg (white) & \\
\hline Vegetables & $5 \pm 3.5$ \\
\hline Water leaf (Talinum triangulare) & $<1 \pm 8.4$ \\
\hline Spinach (Ameranthus spp) & $<1 \pm 8.4$ \\
\hline Bitter leaf (Vemonia amygdalina & $<2 \pm 3.2$ \\
\hline Onion (Allum cepa) & $<2 \pm 3.2$ \\
\hline Pepper (Capsicum annum) & \\
\hline
\end{tabular}

\section{Absorption of selenium}

Ingested dietary selenium is absorbed in the small intestine. Both inorganic and organic forms of selenium are all absorbed primarily in the duodenum, jejunum and ileum and to a little extent in the stomach. Vitamins C, A and E speed up selenium absorption [22]. Mercury and phytates may slow down selenium absorption through chelation and precipitation. Dietary selenium in the inorganic form such as selenite elicits greater incorporation of the mineral into glutathione peroxidase than when selenomethionine, the organic forms is the dietary form.
Sodium selenite is efficiently absorbed from the digestive tract in a homeostatically independent pattern. They are then incorporated into sulphur containing protein and albumin $[22,23]$. Selenium replaces the sulfur in cysteine forming selenocysteine, a selenoprotein. There are about twentyfive different types of selenoprotein coded by twenty five selenoprotein genes in humans [24,25] (Table 3).

Table 3:Selenium content in North-Central region of Nigeria [44].

\begin{tabular}{|c|c|c|}
\hline Tuber & $\begin{array}{c}\text { City with Highest } \\
\text { Selenium Level }\end{array}$ & $\begin{array}{c}\text { City with Lowest } \\
\text { Selenium Level }\end{array}$ \\
\hline Yam & Makurdi & $\begin{array}{c}\text { Bida, Abuja, Lafiagi } \\
\text { and Jos }\end{array}$ \\
\hline Sweet potato & Bida & $\begin{array}{c}\text { Makurdi, Lafiagi } \\
\text { and Jos }\end{array}$ \\
\hline Yellow yam & Lafiagi & $\begin{array}{c}\text { Minna, Bida, Keffi, } \\
\text { Makurdi, Otukpo, } \\
\text { Lokoja and Ilorin }\end{array}$ \\
\hline
\end{tabular}

\section{Storage of selenium}

Selenium is stored in the tissues in varying concentrations: $30 \%$ in the liver, $30 \%$, in the muscle, $15 \%$ in kidney, $10 \%$ in the plasma and the remaining $15 \%$ throughout other organs $[8,26]$. Concentrations of free selenium are greatest in the renal cortex and pituitary gland, followed by the thyroid gland, adrenals, testes, ovaries, liver, spleen, and cerebral cortex $[8,27,28]$.

\section{Metabolism of selenium}

Selenium undergoes reduction and methylation. Sodium selenite crosses the plasma membranes and reacts with methyl cytoplasmic thiols in the reduction pathway forming selenide, which is then methylated, giving rise to methylated selenium derivatives that are excreted in urine, expired air via the lungs, and feces $[29,30]$. The proportion of selenium intake excreted depends on dietary intakes [31-33].

\section{Bioassay of selenium}

Selenium concentrations are typically measured in plasma $[8,12]$, serum, whole blood, amniotic fluid, and urine as well as hair and toenails [8]. The main methods devised in the assay of the mineral are atomic absorption spectrometry and inductively coupled plasma-mass spectrometry. 
According to the World Health Organization, the proposed optimal concentration of selenium in plasma for healthy adults is $39.5-197.4 \mathrm{ng} / \mathrm{ml}$ (or $0.0395-0.1974 \mu \mathrm{g} / \mathrm{ml}$ ) [8]. Glutathione peroxidase reaches maximal activity when serum selenium concentrations are between 70-90ng/mL which can be achieved through dietary intakes of selenium 55-65 $\mu$ g/day. Studies reveal that selenoprotein $\mathrm{P}$ is the main supplier of selenium to tissues in the body $[8,34]$. Selenoprotein P reaches its peak expression when serum selenium concentrations are considerably higher than those required to maximize the glutathione activity, around $125 \mathrm{ng} / \mathrm{mL}$ [8].

\section{Selenium Distribution in Nigerian Land}

Rocks are sources of soil minerals. Like other countries, Nigeria is endowed with three types of rocks: sedimentary, igneous and metamorphic rocks. Sedimentary rocks are present in Niger state, Southern states and North-West. Igneous rocks are located in Jos Plateau. Together with metamorphic rocks, the igneous rocks form the oldest crystalline solid physical foundation of the nation [35].

Soil type in Nigeria includes sandy soils characterizing the northern region in the sahel savanna belt, Laterite soil, forest soil in the south and alluvial soils in the flooded plains of rivers or deltas or along the coastal flats [35]. Apart from rock, soil, plant and animal, selenium is also produced by burning of hydrocarbons, volcanic eruptions, mining and milling of minerals [36].

In West Africa, Senegal has the highest soil selenium concentration [37]. Available evidence shows that the plasma selenium concentration in African countries, such as Burundi, Zambia, Malawi, Zaire and Nigeria is inadequate [25]. Analysis of soil selenium in erosion-challenged Oba and Nanka communities, located in South-Eastern zone of Nigeria showed low concentrations of selenium in soil $(0.48 \pm 0.32 \mathrm{PPM}$ and $0.32 \pm 0.32 \mathrm{PPM}$ respectively) [5] and water $(0.03 \pm 0.01 \mathrm{PPM}$ and $0.04 \pm 0.01 \mathrm{PPM}$ respectively). Therefore, in the absence of supplementation, plants and animals grown in these communities may exhibit low selenium levels.

The mean soil selenium level around the derelict Udege Mines of Nassarawa state in the North-Centre geopolitical zone was reported to be $5.03 \mathrm{mg} / \mathrm{kg}$, exceeding WHO recommendation $(0.5 \mathrm{mg} / \mathrm{kg})[38]$. Despite the fact that seleniferous soils have high soil selenium contents, excess soil and water selenium levels may lead to accumulation of the mineral in plant and animal bodies resulting into deleterious effects in humans [38]. Water selenium levels exceeding reference level $(0.01 \mathrm{mg} / \mathrm{L})$ may elicit adverse effects.

Oklo et al. [39] documented the soil selenium contents of some areas in kogi state, North-Central region of Nigeria, with low levels recorded in Ojebe and Ofarachi areas and high level in Ogume area only. In the same vein, the average level of selenium in selected areas of Cross river and Akwa Ibom states, South-
South geopolitical zone of Nigeria was $2.86 \pm 3.97 \mathrm{mgldl}$ [40]. Factors which may account for variation of selenium in Nigeria are:

1. Rainfall: In Nigeria, the coastal region around Niger Delta region in South-Southern region of Nigeria receives annual around $4,000 \mathrm{~mm}$ (157.5in) of rainfall. In North Eastern state of Borno, the annual rainfall is below $1500 \mathrm{~mm}$. In most Southern States, the annual rainfall is above $2,000 \mathrm{~mm}$. Selenium tends to the concentrated in the soil of the drier regions of the world [41].

2. Soil pH: In acidic poorly aerated soils, selenium is relatively unavailable to plants because it is present mainly as insoluble selenite complexes [41].

3. Geographical factors: The selenium content of food varies widely depending on geographic locations [42]. For example, Nanka community of Anambra state in SouthEastern Nigeria, is an erosion ridden environment. Soil selenium in this area was reported to be low [5]. Low soil selenium correlates positively with secondary diseases. An example of secondary diseases is Keshan disease, a disease that affects some people that live in South-West China, where the soil is selenium deficient.

4. Soil composition: Phosphates present in rock, shales, limestones and sand stone contain selenium. Sulphide mineral deposit reduces selenium level.

5. Analytic methods: Methods devised in estimating soil selenium level give results which may not be the same $[6,43]$.

\section{Selenium Concentration in Nigerian Foods}

Since plants depend on raw materials of soil origin, soil selenium content determines selenium availability in the body. Exposure to selenium is majorly through food. Brazilian nut has the highest selenium concentration $0.54 \mathrm{mg} / \mathrm{kg}$.

In Anambra state, South-Eastern region, analysis of cassava tuber in Nanka and Oba communities showed that selenium contents were low $0.16 \pm 0.03 \mathrm{PPM}$ and $0.15 \pm 0.02 \mathrm{PPM}$ respectively [5]. Tubers are a major staple food in Nigeria, especially in rural communities. Decreased selenium in tubers may portend risk to the health of people.

Study by Abulude et al. [6] examined both local and imported products. It is interesting to observe that cassava flour, Cray fish and tilapia had the highest selenium concentrations. Wistar rats, snails, egg yolk, egg white, spinach, pepper and bitter leaf contained low selenium levels. Conversely, in Northern Europe, foods which contained high selenium level include meat, poultry, and fish (49). Difference in soil selenium levels, presence of high level of phytate, sulphur and mercury and difference in analytical methods employed might account for the discrepancy between the low selenium level reported by [5] and the findings of Abulude et al. [6]. 
Analysis of average selenium content in root and tuber plants in North-Central by Zarmai et al. [43] showed that sweet potato contains $19.2 \pm 5,20 \mu \mathrm{g} / \mathrm{kg}$, yellow yam has $18.3 \pm 6.97 \mu \mathrm{g} / \mathrm{kg}$, yam has $13.6 \pm 7.12 \mu \mathrm{g} / \mathrm{kg}$ and cassava has $13.0 \pm 5.84 \mu \mathrm{g} / \mathrm{kg}$. Yellow yam from Lafia had the highest level $76.3 \mu \mathrm{g} / \mathrm{kg}$ while Minna, Bida, Keffi, Makurdi, Otukpo, Lokoja and Ilorin had a mean of $18.3 \pm 6.97 \mu \mathrm{g} / \mathrm{kg}$. Sweet potato from Bida showed the highest selenium level while Makurdi, Lafiagi and Jos had a mean value of $19.2 \pm 5.20 \mu \mathrm{g} / \mathrm{kg}$. Yam from Makurdi contained the highest selenium concentration $81.8 \mu \mathrm{g} / \mathrm{kg}$ while that from Bida, Abuja, Lafia, Gboko, Lokoja, Idah, Ilorin, Lafiagi and Jos showed a mean of $13.6+7.12 \mu \mathrm{g} / \mathrm{kg}$. From the work of Zarmai et al. [43], sweat potato in North-Central region had the highest selenium content followed by yellow yam, yam and cassava.

Study by Orisakwe et al. [44] estimated the levels of selenium in fifty (50) beverages purchased in Nigeria using the Atomic Absorption Spectrophotometer (AAS). The result indicated that selenium levels ranged from $0.24-1.67 \mathrm{mg} / \mathrm{L}$ for canned beverages and $0.07-1.23 \mathrm{mg} / \mathrm{L}$ for non-canned beverages. $95 \%$ of canned beverages had selenium levels that exceeded the maximum Contaminant Level (MCL) set by United States Environmental Protection Agency (USEPA) (MCL) whereas 90\% of the non-canned products had selenium levels above the MCL.

Different brands of bottled beer marketed in Makurdi town exhibited selenium content that exceeded maximum contaminant level. On the contrary, Obahiagbon et al. [45] reported that selenium concentration in vegetable, waterleaf, ewedu leaf, bitter leaf, cocoyam leaf, green pepper leaf and okra leaf were within permissive level.

The above findings showed the variations in food selenium levels. Local foods grown in erosion prone regions may have lower selenium concentrations. This may lead to a decrease in selenium level in animals and humans that consume the foods.

\section{Human Selenium Requirement}

The recommended daily allowances (RDA) of selenium at $55 \mu \mathrm{g} /$ day (WHO/FAO/IAEA, 1996) for both adult males and females by Food and Nutrition Board at the Institute of Medicine. This amount is based on the amount of dietary selenium needed for activity of selenium-containing enzyme glutathione peroxidase in the plasma. The tolerable upper limit of selenium is $0.4 \mathrm{mg} /$ day (WHO/FAO/IAEA, 1996). Excess consumption of selenium may result in brittle nail, garlic breath, nausea and vomiting. 10 gram oral dose of selenium dioxide can cause death. The lethal doses (LD50) for orally administered selenate in rats are 7 to $22 \mathrm{mg} / \mathrm{kg}$ body weight [46] and between 3 and $12 \mathrm{mg} /$ $\mathrm{kg}$ body weight for orally administered sodium selenite in rats $[47,48]$.

\section{Selenium Levels in Nigerians}

Kolawole \& Obueh [41] reported that the mean serum selenium level of people in selected areas of Akwa Ibom and Cross River state, South-South region of Nigeria, was $0.006 \mathrm{mg} / \mathrm{L}$.
Okwara et al. [49] got $0.29 \pm 0.09 \mathrm{mmol} / \mathrm{L}(57.6 \pm 14.4 \mathrm{mg} / \mathrm{L})$ for healthy male adults and $0.28 \pm 0.08 \mathrm{mmol} / \mathrm{L}(50.4 \pm 16.2 \mathrm{mg} / \mathrm{L})$ for healthy adult female in Orlu, South-East Nigeria. Nwagha et al. [50] also found a plasma selenium concentration of $1.38 \pm 0.18 \mu \mathrm{mol} / \mathrm{l}(0.245 \pm 0.0324 \mathrm{mg} / \mathrm{L})$ in healthy female subjects in the South-East region.

The mean plasma selenium of 88 healthy adults in Abeokuta, South-Western region of Nigeria, was $0.188 \pm 0.026 \mathrm{mg} / \mathrm{L}$ [13]. Arinola et al. [51] obtained a level of $57.05 \pm 2.50 \mu \mathrm{g} / \mathrm{L}$ $(0.057 \pm 0.0025 \mathrm{mg} / \mathrm{L})$ in healthy female Nigerians in SouthWestern region. The plasma selenium level in a study by Anyabolu et al. [10] was $9.81 \pm 1.6 \mu \mathrm{g} / \mathrm{dL}(0.0981 \pm 0.016 \mathrm{mg} / \mathrm{L})$ in children in South-Western region. Sixty healthy subjects of over 18 years of age in an area in Osun state, South-Western region, had a mean serum selenium level of $32.79 \pm 5.46 \mu \mathrm{g} / \mathrm{dl}$ $(0.3279 \pm 0.0546 \mathrm{mg} / \mathrm{L})$ [52]. Oyedeji et al. [53] also obtained a plasma level of $1.02 \pm 0.01 \mu \mathrm{mol} / \mathrm{L}(0.1836 \pm 0.0018 \mathrm{mg} / \mathrm{L})$ in healthy female subjects in South-Western region. Karaye etal. [14] obtained a plasma level of $118.4 \pm 45.6 \mu \mathrm{g} / \mathrm{L}(0.118 \pm 0.0456 \mathrm{mg} / \mathrm{L})$ in a selected area of North-West region of Nigeria.

In addition to plasma selenium level, physiological balance in selenium distribution between body fluid compartments may be important as far as state of health is concerned. For instance, the ratio of serum selenium to seminal plasma selenium was found to be 1:1 in healthy adult male in South-West of Nigeria [12]. In developing country like Nigeria where a sizeable population of people lives on local foods which may not contain high selenium contents due to soil factors, the selenium concentrations in body fluids would be expected to vary across the geopolitical zones. Despite this, the selenium content in Nigeria putting all these studies together may vary from $0.006 \mathrm{mg} / \mathrm{L}$ to $0.3279 \pm 0.0546 \mathrm{mg} / \mathrm{L}$.

Factors which may affect the plasma and tissue concentrations of the mineral may interfere with the physiological functions of the mineral. Such factors may include:

a. Age: Plasma selenium is lower in children than adult [54].

b. Genetic variation affects the plasma and tissue levels of selenium [55].

c. Gender: Males have slightly higher plasma selenium than female [54].

d. Pathological conditions including Acquired Immune Deficiency Syndrome [50,57,58], infertility [12], diabetes mellitus [15] and digestive problems [11] decrease plasma and tissue selenium.

e. Pregnancy and lactation [50] decrease plasma selenium level.

f. State of activity: Exercise increases the need for selenium [34] and sedation may reduce plasma selenium level [11]. 
g. Kidney dialysis reduces plasma selenium [11].

h. Lifestyle such as smoking, alcoholism and vegetarianism may reduce plasma selenium level [54].

i. Oral contraceptive use $[13,58]$ reduces selenium level.

\section{Physiological Functions of Selenium}

\section{Immunity}

Many local studies have documented that HIV-positive subjects exhibited low plasma selenium with male subjects having lower serum selenium levels than female subjects $[10,11,59]$. Report also indicates that HIV positive subjects with and without skin diseases exhibited low serum selenium [60]. The virus is known to incorporate selenium into its Human-Like glutathione peroxiadase leading to a decline in serum selenium and glutathione in the host [61].

The prevalence of HIV infected children is high [10]. Therefore, there is incontestable need for selenium supplementation. Selenium is an active component of selenoproteins which include thioredoxin reductase and glutathione peroxidase. In Nigeria, the plasma glutathione was estimated in a study as $0.127 \pm 0.022 \mathrm{U} / \mathrm{mL}$. Therefore, selenium supplementation may improve glutathione defense system. Positive immune outcome achieved with respect to selenium supplementation includes improvement in CD4 counts in HIV-positive Nigerian subjects. In west Africa, Senegal has the highest soil selenium contents and this has been linked with lower prevalence of HIV in the country [37].

In animal studies, selenium supplementation together with vitamin E, increased packed cell volume in trypanosome Brucei Brucei infected rats [18]. It also reduced susceptibility of black marshal cockerel to infectious bursal disease [62].

\section{Reproduction}

Selenium supplementation may improve testosterone level in male. Testes and ovaries are among organs that contain greatest concentrations of free selenium [27]. Upset in physiological balance between serum and seminal plasma selenium was associated with oligospermia and azoospermia in a study by Akinloye et al. [12]. Selenium supplementation improved reproductive of rabbits does by enhancing follicle stimulating hormone and oxidative enzyme. Low selenium level was found in subjects with prostate cancer [57].

\section{Endocrinology and metabolism}

Female diabetics drawn from Calabar showed higher serum selenium level than diabetic male [15]. Together with zinc, selenium reduced blood glucose concentration, restored hepatic functions and reduced hepatic and renal lipid peroxidation of diabetic rats [63]. Ahmed et al. [16] reported that selenium possessed a hypoglycemic property comparable to glibenclamide in rats.

\section{Gastrointestinal health}

Selenium supplementation may also exert positive influence on gastrointestinal function and health. In an animal experiment conducted by Adeniyi et al. [13], supplementation with selenium accelerated gastric ulcer healing by facilitating mucosal regeneration and antioxidant activity and by reducing lipid peroxidation. Together with vitamin E, selenium demonstrated tendency to assuage adverse effects in an experimental model of acute gastric ulceration in rats [64].

\section{Cardiovascular health}

In South western China, selenium deficiency was associated with cardiomyopathy called Keshan disease. Also in Nigeria, a study by Karaye et al. [14] in an area in North-West region of Nigeria indicated that female subjects with Postpartum Cardiomyopathy had low serum selenium level that was due to insufficient dietary intake of the mineral [65-74].

\section{Conclusion}

There are variations in selenium levels across the geopolitical zones in Nigeria with a nadir of $0.006 \mathrm{mg} / \mathrm{L}$ and a zenith of $0.3279 \pm 0.0546 \mathrm{mg} / \mathrm{L}$. Hence, there is need for selenium supplementation. This review also provides evidence that selenium supplementations can improve health status of Nigerians.

\section{References}

1. Ellie W, Sharm RR (2013) Understanding nutrition $\left(13^{\text {th }}\right.$ edn), Wadsworth Publishing, USA, pp. 667- 670.

2. Opstad K (1994) Circadian rhythm of hormones is extinguished during prolonged physical stress, sleep and energy deficiency in young men. Eur J Endocrinol 131(1): 56-66.

3. Rayman MP (2000) The importance of selenium to human health Lancet 356(9225): 233-241.

4. Combs GF (2001) Selenium in global food systems. Br J Nutr 85(5): 517-547.

5. Olife, Ifeyinwa C, Anajekwu, Azuka B (2013) Iodine and selenium distribution in the local environment of selected villages in anambra state. Nigeria' Journal of Natural Sciences Research 3(5): 116-118.

6. Abulude F, Ogunkoya M, Orojo T (2006) Selenium in Nigerian foods. Ejipau Anim Reprod 10(4): 677-683.

7. Rayman MP (2012) Selenium and human health. Lancet 379(9822): 1256-1268.

8. Hiten MD, Pipkin FB, Redman CWG, Poston L (2012) Selenium in reproductive health. American Journal of Obstetrics \& Gynecology 206(1): 21-30.

9. Odonukwe NN (2006) The role of selenium as adjunct to HAART among HIV-infected individuals who are advanced in their disease. Sixteenth International AIDS Conference, Toronto, Canada, abstract no: Ab0403.

10. Anyabolu HC, Adejuyigbe EA, Adeodu OO (2014) Serum micronutrient status of haart-naïve, HIV infected children in south west Nigeria. A case controlled study. AID Research and Treatment 351043.

11. Kalio IS (2014) Comparative study of selenium and zinc antioxidant in HIV sero positive individuals. IOSR Journal of Pharmacy and Biological Sciences 9(4): 47-50 
12. Oluyemi A, Arowojolu AO, Shittu OB, Adejuwon CA, Osotimehin B (2005) Selenium status of idiopathic infertile Nigerian males. Biological Trace Element Research 104(1): 9-18.

13. Babalola 00, Anetor JI, Adeniyi FAA (2003) Assesment of selenium status of healthy adults in south western Nigeria. Asset series 3(4): 111-120.

14. Kamilu KM, Yahaya IA, Lindmark K, Henein MY (2015) Serum selenium and ceruloplasmin in nigerians with peripartum cardiomyopathy. Int J Mol Sci 16(4): 7644-7654.

15. Augusta N, Adanna C, Usoro O, Henrietta M, Isonguyo E, et al. (2006) Influence of age; gender and duration of diabetes on serum and urine levels of zinc, magnesium and selenium in calabar Nigeria. Turk J Bioch 31(3): 107-114

16. Kabir AM, Aliyu M, Yusuf T, Yusuf MK (2015) Ameliorative effect of selenium yeast on blood glucose level in streptozotocin induced diabetes in wistar rats. Cell Biology 3(1): 14-18.

17. ZhangX, ZarbiH(2008) Chemoprotective doses of methylselenocysteine alter circadian rhythm in rat mammary tissue. Cancer 1(12): 119-127.

18. Yakubu DP, Dawet A, Olaleye NA (2014) Effects of vitamin and selenium on some blood parameters trypanosoma brucei infected rats. British Journal of Applied Science \& Technology 4(7): 1100-1108.

19. Norman GN, Earnshaw A (1997) Chemistry of the elements, ( $2^{\text {nd }}$ edn), Butterworth-Jheinemann, UK, pp. 751-752.

20. Oldfield JE (1987) The two faces of selenium. J Nutr 117(12): 2002 2008.

21. Schwarz K, Foltz CM (1957) Selenium as an integral part of factor 3 against dietary necrotic liver degeneration. J Am Chem Soc 79(12): 3292-3293

22. Reilly C (2006) Selenium in food and health. Springer, New York, USA.

23. Robinson MF, Godfrey PJ, Thomson CD, Rea HM, Van-Rij AM (1979) Blood selenium and glutathione peroxidase activity in normal subjects and in surgical patients with and without cancer in New Zealand. Am J Clin Nutr 32(7): 1477-1485.

24. Kryukov GV, Castellano S, Novoselov SV (2003) Characterization of mammalian selenoproteomes. Science 300(5624): 1439-1443.

25. Hogenkamp M, Lungu OI (2007) Mitigating HIV/AIDS in sub-saharan africa through selenium in food golden valley agricultural research trust.

26. Thomson CD, Stewart RDH (1973) Metabolic studies of [75Se] selenomethionine and [75Se] selenite in the rat. Br J Nutr 30(1): 139147.

27. Drasch G, Mail Der S, Schlosser C, Roider G (2000) Content of nonmercury-associated selenium in human tissue. Biol Trace Elem Res 77(3): 219-230

28. Kohrle J, Jakob F, Contempre B, Dumont JE (2005) Selenium, the thyroid, and the endocrine system. Endocr Rev 26(7): 944-984.

29. Sunde RA (1990) Molecular biology of selenoproteins. Annu Rev Nutr 10: 451-474.

30. Ip C (1998) Lessons from basic research in selenium and cancer prevention. J Nutr 128(11): 1845-1854.

31. Robinson MF, McKenzie JM, Thomson CD, Van Rij AL (1973) Metabolic balance of zinc, copper, cadmium, iron, molybdenum and selenium in young New Zealand women. Br J Nutr 30(2): 195-205.

32. Krupinski T, Beitel GJ (2009) Unexpected roles of the Na-K-ATPase and other ion transporters in cell junctions and tubulogenesis. Physiology 24(3): 192-201.
33. Oster O, Prellwitz W (1990) The renal excretion of selenium. Biol Trace Elem Res 24(2): 119-146.

34. Hurst R, Armah CN, Dainty JR, Hart DJ, Teucher B, et al. (2010) Establishing optimal selenium status: Results of a randomized, doubleblind, placebo-controlled trial. Am J Clin Nutr 91(4): 923-931.

35. Okpo U, Christian EC, Nnaemeka (2013) Global Journal of Science Frontier Research 13(10).

36. National Toxicology Program Report (1994) NTP technical report on toxicity studies of sodium selenate and sodium selenite administered in drinking water to F344/N rats and B6C3F1 Mice. Toxic Rep Ser 38: 1-E5.

37. Wilson Lawrence (2011) Selenium and its mighty benefits. Journal Alternatives 12(14): 105-111.

38. Aremu MO, Atolaiye BO, Labaran L (2010) Environmental implication of metal concentrations in soil, plant foods and pond in area around the derelict udege mines of nasarawa state, Nigeria. Bull Chem Soc Ethiop 24(3): 351-360.

39. Oklo AD, ShaAto R, Asemave L, Ckurzurum (2013) Selenium contents in some brands of bottled beer marketed in Markurdi Town Benue State, Nigeria. Int Journal of Science and Research 2(3): 457-459.

40. Sunday KE, Henrietta OO (2013) Relationship between soilcontents and plasma levels of selenium, chromium and manganese in healthy adult Nigerians. African Journal of Biotechnology 12(34): 5339-5346.

41. Lyons G, Stangoulis J, Graham R (2003) Nutriprevention of disease with high-selenium wheat. Nutr \& Environ Med 22: 3-9.

42. Rayman MP (2008) Food-chain selenium and human health: Emphasis on intake. Br J Nutr 100(2): 254-268.

43. Saidu Z, Eneji IS, Sha'Ato R (2013) Analysis of selenium content in root and tuber plants in central Nigeria. American Journal of Analytical Chemistry 4(12): 739-743.

44. Orisakwe OE, Oragwu CI, Maduabuchi JMU, Nzegwu CN, Nduka JKC (2009) Copper, selenium and zinc content of canned and noncanned beverages in Nigeria. African Journal of Environmental Science and Technology 3(1): 042-049.

45. Obahiagbon FI, Oboh H, Ilori UGE, Agho I (2011) Selenium contents of some commonly consumed nigerian vegetables and physiological implications. Chemical society of Nigeria. Chem Soc Nigeria 36(2): 2011.

46. Henschler D, Kirchner U (1969) On the absorption and toxicity of selenium sulfide. Arch Toxikol 24(4): 341-344.

47. Morss SG, Olcott HS (1967) Absence of effect of tocopherol on acute oral toxicity of sodium selenite in the rat. Proc Soc Exp Biol Med 124(2): 483-485.

48. Cummins LM, Kimura ET (1971) Safety evaluation of selenium sulfide antidandruff shampoos. Toxicol Appl Pharmacol 20(1): 89-96.

49. Okwara EC, Meludu SC, Okwara JE, Enwere OOD, Diwe KC, et al. (2012) Selenium, zinc and magnesium of HIV positive adult presenting at a university teaching hospital in orlu eastern Nigeria. Niger J Med 21(2): 165-168.

50. Nwagha UI, Ogbodo SO, Ikojo ENN, Ibegbu DM, Ejezie FE, et al. (2011) Copper and selenium status of healthy pregnant women in Enugu, southeastern Nigeria. Nigerian Journal of Clinical Practice 14(4): 408412 .

51. Arinola OG, Davies CMA (2008) Micronutrient levels in the plasma of Nigerian females with breast cancer. African Journal of Biotechnology $7(11): 1620-1623$. 
52. Samuel AA, Oparinde DP, Jimoh AK, Babatunde OA, Adelekan A, et al. (2012) Oxidative stress and serum selenium in HIV patients on different antiretroviral regimen. Greener Journal of Medical Sciences 2(6): 163-167.

53. Oyewole OS, Adesina AA, Oke OT, Tijani YO (2014) Evaluation of essential trace elements in female type II diabetic patients in Nigerian population. African Journal of Biotechnology 13(18): 1910-1914.

54. Lillico DAJ, Reid ME, Turnbull BW, Combs GF, Slate EH, et al. (2003) Hyperthyroidism and Hypothyroidism. American Association of Clinical Endocrinologists 462- 465.

55. Penney KL, Schumacher FR, Li H, Kraft P, Morris JS, et al. (2010) A large prospective study of sep15 genetic variation, interaction with plasma selenium levels, and prostate cancer risk and survival. Cancer Prev Res 3(5): 604-610.

56. Durosinmi MA, Armistead H, Akinola NO, Onayemi O, Adediran IA, et al. (2008) Selenium and aspirin in people living with HIV \& AIDS in Nigeria. Niger Post grad Med J 15(4): 215-218.

57. Famurewa AC, Akinosun OM (2014) Plasma levels of $\alpha$-tocopherol, $\gamma$-tocopherol and selenium in patients with prostate cancer in Nigeria. International Journal of Medicine and Biomedical Research 3(3): 161167.

58. Moore JA, Noiva R, Wells IC (1984) Selenium concentrations in plasma of patients with arteriographically defined coronary artherosclerosis. Clin Chem 30(7): 1171-1173.

59. Ajayi GO, Omilabu SA (2003) Magnesium, selenium, zinc, copper and CD4 count in HIV $1 \& 2$ positive nigerians attending prepregnancy class. Prenatal Diagnosis \& Therapy Centre of Lagos University 20(4): 203-204.

60. Oladayo AA, Mejiuni DA, Onayemi O, Ayodele OE, Atiba AS, et al. (2013) Serum selenium and skin diseases among Nigerians with human immunodeficiency virus/acquired immune deficiency syndrome. HIV AIDS (Auckl) 5: 215-221.

61. Frackiewicz LA (2005) The role of selenium in cancer and viral infection prevention. Int J Occup Med Environ Health 18(4): 305-311.

62. Eze JI, Okeke MC, Ngene AA, Omeje JN, Abonyi FO (2013) Effect of dietary selenium supplementation on parasitemia, anemia and serum proteins of trypanosomia brucei brucei infected rats. Elsevier 135(2): 331-336.

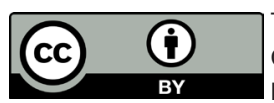

This work is licensed under Creative

Commons Attribution 4.0 License

DOI: 10.19080/CTBEB.2018.14.555876
63. Uyoyo U, Ngozi JO, Temitayo I, Dele A (2010) Antioxidant effects of zinc, selenium and their combination in liver and kidney of alloxan-induced diabetes in rats. Mediterranean Journal of Nutrition and Metabolism 3(1): 25-30.

64. Sauda Y, Adelaiye AB, Magaji RA, Ayo JO, Mabrouk MA (2015) Role of selenium and vitamin e on gastric mucosal damage induced by water immersion restrainst stress in wistar rats. Journal of Pharmacy and Biological Sciences 10(1): 34-39.

65. Adegbola SA (1979) An agricultural atlas of Nigeria. Oxford University Press, Oxford, UK.

66. Geering HR, Cary EE, Jones LHP, Allaway WH (1968) Solubility and redox criteria for the possible forms of selenium in soils. Soil Sci Soc Am Proc 32: 3540.

67. Institute of Medicine, Food and Nutrition Board (2000) Dietary reference intake for vitamin $\mathrm{C}$, vitamin $\mathrm{E}$, selenium and carotenoids. National Academic Press, Washington DC, USA.

68. Ministry of Agriculture Fisheries and Food (1997) Dietary intake of selenium. Joint Food Safety and Standards Group, HM Stationery Office, London, UK.

69. Ejike OC, Meludu SC, Dioka CE, Nnamah NK, Nnoli JK, et al. (2015) The level of testosterone, zinc, manganese and selenium in type 2 diabetic patient in south-eastern Nigeria. Int J Res Med Sci 3(5): 1138-1141.

70. Online Nigeria (2015) Nigeria's identifiable ethnic groups. Otite O Check date values.

71. Perry-Castañeda Library (1987) Nigeria: giant of Africa. In: Peter Holmes (Ed.), Austin, Texas, USA.

72. Audu S, Oladele SB, Abdu PA, Najume, Dogon, et al. (2012) Effect of selenium on the susceptibility of vaccinated cockerels against infectious Bursal Disease. I Vet Adv 2(12): 573-579.

73. Ugwuja EI, Ugwu NC, Aloke C, Idenyi JN, Nwibo AN, et al. (2012) Effects of glycaemic status on plasma levels of calcium, chromium, copper, iron, magnesium, selenium and zinc in diabetic rats. International Journal of Diabetes Research 1(5): 92-95.

74.WHO/FAO/IAEA (1996) Trace elements in human nutrition and health. World Health Organization. Geneva, pp. 6-10.

Your next submission with Juniper Publishers
will reach you the below assets
- Quality Editorial service
- Swift Peer Review
- Reprints availability
- E-prints Service
- Manuscript Podcast for convenient understanding
- Global attainment for your research
- Manuscript accessibility in different formats
( Pdf, E-pub, Full Text, Audio)
- Unceasing customer service
Track the below URL for one-step submission
https://juniperpublishers.com/online-submission.php

